
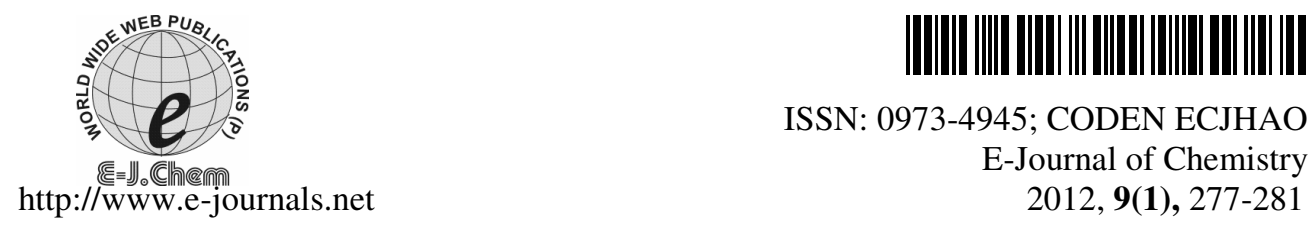

ISSN: 0973-4945; CODEN ECJHAO

E-Journal of Chemistry

2012, 9(1), 277-281

\title{
Pyridinedicarboxylic Acid Derivatives of Dichlorobis(cyclopentadienyl)titanium(IV)
}

\author{
SATISH C. DIXIT* and ROHIT K. SINGH \\ *Deptt. of Chemistry, D.B.S.(P.G.) College, Kanpur-208006, India \\ Deptt. of Chemistry, Pt. J.L.N. College, Banda(U.P.), India \\ satishdixit1@gmail.com
}

Received 19 April 2011; Accepted 2 July 2011

\begin{abstract}
Reactions of dichlorobis(cyclopentadienyl)titanium(IV) with pyridine dicarboxylic acids viz. quinolinic acid $\left(\mathrm{QAH}_{2}\right), 2$,4-pyridine dicarboxylic acid $\left(\mathrm{PAH}_{2}\right)$, isocinchomeronic acid $\left(\mathrm{IAH}_{2}\right)$, cinchomeronic acid $\left(\mathrm{CAH}_{2}\right)$ and dinicotinic acid $\left(\mathrm{DAH}_{2}\right)$ were carried out in different stoichiometric ratios. Complexes of the type $\mathrm{Cp}_{2} \mathrm{Ti}(\mathrm{QAH}) \mathrm{Cl}, \mathrm{Cp}_{2} \mathrm{Ti}(\mathrm{QAH})_{2}, \mathrm{Cp}_{2} \mathrm{Ti}(\mathrm{PAH}) \mathrm{Cl}, \mathrm{Cp}_{2} \mathrm{Ti}(\mathrm{PAH})_{2}$, $\mathrm{Cp}_{2} \mathrm{Ti}(\mathrm{IAH}) \mathrm{Cl}, \mathrm{Cp}_{2} \mathrm{Ti}(\mathrm{IAH})_{2}, \mathrm{Cp}_{2} \mathrm{Ti}(\mathrm{CAH}) \mathrm{Cl}, \mathrm{Cp}_{2} \mathrm{Ti}(\mathrm{CAH})_{2}, \mathrm{Cp}_{2} \mathrm{Ti}(\mathrm{DAH}) \mathrm{Cl}$ and $\mathrm{Cp}_{2} \mathrm{Ti}(\mathrm{DAH})_{2}$ were obtained. These new complexes were characterized on the basis of their elemental analyses, electrical conductance, magnetic moment and spectral data.
\end{abstract}

Keywords: $\mathrm{Cp}_{2} \mathrm{TiCl}_{2}$, Pyridinedicarboxylic Acids, Synthesis, Characterization, Complex

\section{Introduction}

Pyridine dicarboxylic acids form stable chelates with simple metal ions and oxometal cations ${ }^{1-6}$. A very important characteristic of these ligands is their diverse biological activity ${ }^{7-8}$. Considerable work has been performed in developing therapeutic analogues of $\mathrm{Cp}_{2} \mathrm{TiCl}_{2}$ by varying the central metal, the labile ligands $(\mathrm{Cl})$ and the bis-cyclopentadienyl moiety. In particular, small changes to the $\mathrm{Cp}$ ligand can strongly affect the hydrolytic stability and water solubility properties of the metallocenes and have an impact on the cytotoxic activity. Most of the analysed titanocene complexes have polar substituents on the cyclopentadienyl ring such as alkoxo, amino or electron - withdrawing groups as carboxylic acid and esters which have demonstrated in some cases a very high activity in antitumoral tests ${ }^{9-16}$.

A survey of the literature reveals that no work has been carried out on the reactions of $\mathrm{Cp}_{2} \mathrm{TiCl}_{2}$ with quinolinic acid, 2,4-pyridinedicarboxylic acid, isocinchomeronic acid, cinchomeronic acid and dinicotinic acid. It was, therefore, considered of interest to carry out 
the reactions of dichlorobis(cyclopentadienyl)titanium(IV) with quinolinic acid, 2,4-pyridine dicarboxylic acid, isocinchomeronic acid, cinchomeronic acid and dinicotinic acid. The structure of the ligands used is given below:<smiles>O=C(O)c1cccnc1C(=O)O</smiles>

2, 3-pyridine dicarboxylic acid

(Quinolinic acid)<smiles>O=C(O)c1ccnc(C(=O)O)c1</smiles>

2, 4-pyridine dicarboxylic acid<smiles>O=C(O)c1ccc(C(=O)O)nc1</smiles>

2, 5-pyridine dicarboxylic acid (Isocinchomeronic acid)<smiles>O=Cc1ccncc1C(=O)O</smiles>

3, 4-pyridine dicarboxylic acid (Cinchomeronic acid)<smiles>O=C(O)c1cncc(C(=O)O)c1</smiles>

3, 5-pyridine dicarboxylic acid

(Dinicotinic acid)

Figure 1. Structure of the ligands used

\section{Experimental}

THF(Ferak, Berlin, FRG) was dried according to the method described ${ }^{17}$. Triethylamine and $n$-hexane were dried by the standard method ${ }^{18}$. Dichlorobis(cyclopentadienyl) titanium(IV) (Aldrich), quinolinic acid (Aldrich), 2,4-pyridinedicarboxylic acid (Aldrich), isocinchomeronic acid (Aldrich), cinchomeronic acid (Aldrich) and dinicotinic acid (Aldrich) were used as supplied. Stringent precautions were taken to exclude the moisture from the system. The reactions were carried out under dry nitrogen with system well protected from atmospheric nitrogen by means of calcium chloride guard tubes.

Analysis for carbon, hydrogen and nitrogen was carried out at the Central Micro Analytical Laboratory of IIT, Kanpur. Titanium was estimated gravimetrically as $\mathrm{TiO}_{2}$. Chlorine was determined as $\mathrm{AgCl}$. The IR spectra were recorded on a Perkin -Elmer 1710 infrared Fourier Transform spectrometer in the region $400-4000 \mathrm{~cm}^{-1}$ in $\mathrm{KBr}$ pellets. The electronic spectra of the complexes in chloroform were recorded on a Shimadzu UV-260 spectrophotometer.

\section{Preparation of complexes}

A general procedure was followed to synthesize the complexes of $\mathrm{Cp}_{2} \mathrm{TiCl}_{2}$ with quinolinic acid; 2,4-pyridinedicarboxylic acid; isocinchomeronic acid; cinchomeronic acid and dinicotinic acid which involved the mixing of the reactants in anhydrous tetrahydrofuran at room temperature in the presence of triethylamine. The reaction mixture was stirred for $\sim 32-42 \mathrm{~h}$. The precipitated $\mathrm{Et}_{3} \mathrm{~N}$. HCl was filtered off and the solvent was removed under reduced pressure. The product so obtained was recrystallized from a $n$-hexane/ THF mixture. The relevant details of the preparative method used and the complexes obtained are summarized in Table 1. The analytical data of these complexes are tabulated in Table 2. 
Table 1. Reactions of $\mathrm{Cp}_{2} \mathrm{Ti} \mathrm{Cl}_{2}$ with pyridinedicarboxylic Acids

\begin{tabular}{|c|c|c|c|c|c|c|}
\hline \multicolumn{3}{|c|}{ Reactants, $g$} & Molar & Stirring & \multirow{2}{*}{ Product } & \multirow{2}{*}{$\begin{array}{c}\text { Colour, Decompo. } \\
\text { Temp }{ }^{\circ} \mathrm{C} \\
\end{array}$} \\
\hline $\mathrm{Cp}_{2} \mathrm{TiCl}_{2}$ & Acid & $\mathrm{Et}_{3} \mathrm{~N}$ & Ratio & Time, $\mathrm{h}$ & & \\
\hline 0.69 & $\mathrm{QAH}_{2}, 0.46$ & 0.28 & $1: 1: 1$ & 32 & $\left(\mathrm{C}_{5} \mathrm{H}_{5}\right)_{2} \mathrm{Ti}(\mathrm{QAH}) \mathrm{Cl}$ & Dark red, 112 \\
\hline 0.85 & $\mathrm{QAH}_{2}, 1.14$ & 0.69 & $1: 2: 2$ & 35 & $\left(\mathrm{C}_{5} \mathrm{H}_{5}\right)_{2} \mathrm{Ti}(\mathrm{QAH})_{2}$ & Dark red, 118(M.P.) \\
\hline 0.79 & $\mathrm{PAH}_{2}, 0.53$ & 0.32 & $1: 1: 1$ & 40 & $\left(\mathrm{C}_{5} \mathrm{H}_{5}\right)_{2} \mathrm{Ti}(\mathrm{PAH}) \mathrm{Cl}$ & Red, 115 \\
\hline 0.75 & $\mathrm{PAH}_{2}, 1.01$ & 0.61 & $1: 2: 2$ & 42 & $\left(\mathrm{C}_{5} \mathrm{H}_{5}\right)_{2} \mathrm{Ti}(\mathrm{PAH})_{2}$ & Red, 118 \\
\hline 0.74 & $\mathrm{IAH}_{2}, 0.50$ & 0.30 & $1: 1: 1$ & 38 & $\left(\mathrm{C}_{5} \mathrm{H}_{5}\right)_{2} \mathrm{Ti}(\mathrm{IAH}) \mathrm{Cl}$ & Reddish brown, 125 \\
\hline 0.71 & $\mathrm{IAH}_{2}, 0.95$ & 0.58 & $1: 2: 2$ & 39 & $\left(\mathrm{C}_{5} \mathrm{H}_{5}\right)_{2} \mathrm{Ti}(\mathrm{IAH})_{2}$ & Red, 135(M.P.) \\
\hline 0.80 & $\mathrm{CAH}_{2}, 0.54$ & 0.33 & $1: 1: 1$ & 30 & $\left(\mathrm{C}_{5} \mathrm{H}_{5}\right)_{2} \mathrm{Ti}(\mathrm{CAH}) \mathrm{Cl}$ & Dark red, 125 \\
\hline 0.83 & $\mathrm{CAH}_{2}, 1.11$ & 0.67 & $1: 2: 2$ & 32 & $\left(\mathrm{C}_{5} \mathrm{H}_{5}\right)_{2} \mathrm{Ti}(\mathrm{CAH})_{2}$ & Red, 122(M.P.) \\
\hline 0.74 & $\mathrm{DAH}_{2}, 0.50$ & 0.30 & $1: 1: 1$ & 35 & $\left(\mathrm{C}_{5} \mathrm{H}_{5}\right)_{2} \mathrm{Ti}(\mathrm{DAH}) \mathrm{Cl}$ & Dark red, 118 \\
\hline 0.85 & $\mathrm{DAH}_{2}, 1.14$ & 0.69 & $1: 2: 2$ & 36 & $\left(\mathrm{C}_{5} \mathrm{H}_{5}\right)_{2} \mathrm{Ti}(\mathrm{DAH})_{2}$ & Light red, 125 \\
\hline
\end{tabular}

Where $\mathrm{QAH}_{2}=$ quinolinic acid; $\mathrm{PAH}_{2}=2,4$-pyridinedicarboxylic acid, $I A \mathrm{H}_{2}=$ isocinchomeronic acid; $\mathrm{CAH}_{2}=$ cinchomeronic acid, $\mathrm{DAH}_{2}=$ dinicotinic acid

Table 2. Characterization data

\begin{tabular}{|c|c|c|c|c|c|c|}
\hline \multirow{2}{*}{ Complex } & \multicolumn{5}{|c|}{ Analysis: found (calc.), \% } & \multirow{2}{*}{$\begin{array}{c}\lambda_{\max }, \mathrm{nm} \\
\left(\text { in } \mathrm{CHCl}_{3}\right)\end{array}$} \\
\hline & $\mathrm{Ti}$ & $\mathrm{C}$ & $\mathrm{H}$ & $\mathrm{N}$ & $\mathrm{Cl}$ & \\
\hline \multirow{2}{*}{$\left(\mathrm{C}_{5} \mathrm{H}_{5}\right)_{2} \mathrm{Ti}(\mathrm{QAH}) \mathrm{Cl}$} & 12.7 & & 3.67 & 3.56 & 9.3 & \multirow{2}{*}{245.4} \\
\hline & $(12.63)$ & & 3.69 & 3.69 & 9.36 & \\
\hline \multirow{2}{*}{$\left(\mathrm{C}_{5} \mathrm{H}_{5}\right)_{2} \mathrm{Ti}(\mathrm{QAH})_{2}$} & 9.36 & 55.16 & 3.5 & & - & \multirow{2}{*}{243.2} \\
\hline & $(9.39)$ & 56.48 & 3.53 & & -- & \\
\hline \multirow{2}{*}{$\left(\mathrm{C}_{5} \mathrm{H}_{5}\right)_{2} \mathrm{Ti}(\mathrm{PAH}) \mathrm{Cl}$} & 12.66 & 52.5 & & & 9.32 & \multirow{2}{*}{250.4} \\
\hline & $(12.63)$ & 53.77 & & & 9.36 & \\
\hline \multirow{2}{*}{$\left(\mathrm{C}_{5} \mathrm{H}_{5}\right)_{2} \mathrm{Ti}(\mathrm{PAH})_{2}$} & 9.35 & & 3.5 & 5.1 & & \multirow{2}{*}{254.2} \\
\hline & (9.39) & & 3.53 & 5.49 & -- & \\
\hline \multirow{2}{*}{$\left(\mathrm{C}_{5} \mathrm{H}_{5}\right)_{2} \mathrm{Ti}(\mathrm{IAH}) \mathrm{Cl}$} & 12.64 & & 3.64 & 3.5 & 9.31 & \multirow{2}{*}{258.0} \\
\hline & $(12.63)$ & & 3.69 & 3.69 & 9.36 & \\
\hline \multirow{2}{*}{$\left(\mathrm{C}_{5} \mathrm{H}_{5}\right)_{2} \mathrm{Ti}(\mathrm{IAH})_{2}$} & 9.35 & 55.7 & 3.49 & & - & \multirow{2}{*}{262.2} \\
\hline & $(9.39)$ & 56.48 & 3.53 & & -- & \\
\hline \multirow{2}{*}{$\left(\mathrm{C}_{5} \mathrm{H}_{5}\right)_{2} \mathrm{Ti}(\mathrm{CAH}) \mathrm{Cl}$} & 12.8 & 53.18 & & & 9.4 & \multirow{2}{*}{258.2} \\
\hline & $(12.63)$ & 53.77 & & & 9.36 & \\
\hline$\left(\mathrm{C}_{5} \mathrm{H}_{5}\right)_{2} \mathrm{Ti}(\mathrm{CAH})_{2}$ & $\begin{array}{l}9.35 \\
030)\end{array}$ & $\begin{array}{c}55.9 \\
56.48\end{array}$ & & & -- & 262.4 \\
\hline \multirow{2}{*}{$\left(\mathrm{C}_{5} \mathrm{H}_{5}\right)_{2} \mathrm{Ti}(\mathrm{DAH}) \mathrm{Cl}$} & 12.59 & & 3.61 & 3.57 & 9.32 & \multirow{2}{*}{248.6} \\
\hline & $(12.63)$ & & 3.69 & 3.69 & 9.36 & \\
\hline \multirow{2}{*}{$\left(\mathrm{C}_{5} \mathrm{H}_{5}\right)_{2} \mathrm{Ti}(\mathrm{DAH})_{2}$} & 9.41 & 55.6 & & 5.38 & --. & \multirow{2}{*}{250.0} \\
\hline & $(9.39)$ & 56.48 & & 5.49 & -- & \\
\hline
\end{tabular}

\section{Results and Discussion}

Reactions of $\mathrm{Cp}_{2} \mathrm{TiCl}_{2}$ with different pyridine dicarboxylic acids viz. quinolinic acid; 2,4-pyridinedicarboxylic acid; isocinchomeronic acid; cinchomeronic acid and dinicotinic acid in 1:1 and 1:2 molar ratios in anhydrous THF in the presence of triethylamine at room temperature may be represented by the following general equation:

$$
\mathrm{Cp}_{2} \mathrm{TiCl}_{2}+\mathrm{LH}+\mathrm{Et}_{3} \mathrm{~N} \underset{\text { Room temp. }}{\stackrel{\mathrm{THF} .}{\longrightarrow}} \mathrm{Cp}_{2} \mathrm{Ti}(\mathrm{L}) \mathrm{Cl}+\mathrm{Et}_{3} \mathrm{~N} \cdot \mathrm{HCl}
$$




$$
\mathrm{Cp}_{2} \mathrm{TiCl}_{2}+2 \mathrm{LH}+2 \mathrm{Et}_{3} \mathrm{~N} \underset{\text { Room temp. }}{\stackrel{\text { THF. }}{\longrightarrow}} \mathrm{Cp}_{2} \mathrm{Ti}(\mathrm{L})_{2}+2 \mathrm{Et}_{3} \mathrm{~N} . \mathrm{HCl}
$$

( where $\mathrm{Cp}=$ cyclopentadienyl; $\mathrm{LH}=\mathrm{QAH}_{2}, \mathrm{PAH}_{2}, \mathrm{IAH}_{2}, \mathrm{CAH}_{2}$, or $\mathrm{DAH}_{2}$ )

All the complexes are crystalline and extremely sensitive to hydrolysis. The complexes are soluble in tetrahydrofuran and chloroform but insoluble in n-hexane and petroleum ether. Magnetic susceptibility values at room temperature of these complexes show their diamagnetic nature. The electrical conductance measurements of these complexes in acetone showed them to be non - electrolyte.

The IR spectra of the complexes invariably exhibit the usual absorptions due to cyclopentadienyl groups at $\sim 3100 \mathrm{~cm}^{-1}[\mathrm{v}(\mathrm{C}-\mathrm{H})], \sim 1435 \mathrm{~cm}^{-1}[\mathrm{v}(\mathrm{C}-\mathrm{C})], \sim 1020 \mathrm{~cm}^{-1}\left[\delta_{\text {i.p. }}(\mathrm{CH})\right.$ and $\sim 810 \mathrm{~cm}^{-1}\left[\delta_{\text {o.p. }}(\mathrm{CH})\right]^{19}$. The persistence of the bands of cyclopentadienyl rings in the complexes indicate that these groups are $\pi$-bonded to the metal and retain their aromatic character. The IR spectral data for the dicarboxylate complexes exhibit the presence of both the "free" carboxylic and coordinated carboxylate groups at $\sim 1700 \mathrm{~cm}^{-1}$ and $1600 \mathrm{~cm}^{-1}$ respectively. This strong evidence prove that only one of the two carboxylic acid groups is bonded to the metal. The pyridine stretch is observed at $\sim 1580 \mathrm{~cm}^{-1}$ in these newly synthesized complexes which indicates the non - involvement of the pyridine nitrogen in the coordination. All these complexes show the ring breathing mode of the pyridine $e^{20-21}$ at about $\sim 998 \mathrm{~cm}^{-1}$. The absorption bands in the region $590-585 \mathrm{~cm}^{-1}$ are assigned to $\mathrm{v}(\mathrm{Ti}-\mathrm{O})$ stretching vibration ${ }^{22-23}$. The electronic spectra of all the complexes recorded in the chloroform show fairly intense bands between 243.2 and $262.4 \mathrm{~nm}$ which can be assigned to the charge transfer band ${ }^{24}$ and is in the accord with their $(n-1) d^{0}$, ns ${ }^{0}$ electronic configuration.

On the basis of elemental analyses, spectral data, electrical conductance and magnetic susceptibility measurements, the following (I \& II) structures (Figure 2) can tentatively be proposed for the complexes, $\left(\mathrm{C}_{5} \mathrm{H}_{5}\right)_{2} \mathrm{Ti}(\mathrm{L}) \mathrm{Cl}$ and $\left(\mathrm{C}_{5} \mathrm{H}_{5}\right)_{2} \mathrm{Ti}(\mathrm{L})_{2}$, respectively.<smiles></smiles>

I<smiles>[R]C1OC[Te]2(c3ccccc3)(O1)OC2CCC</smiles>

II

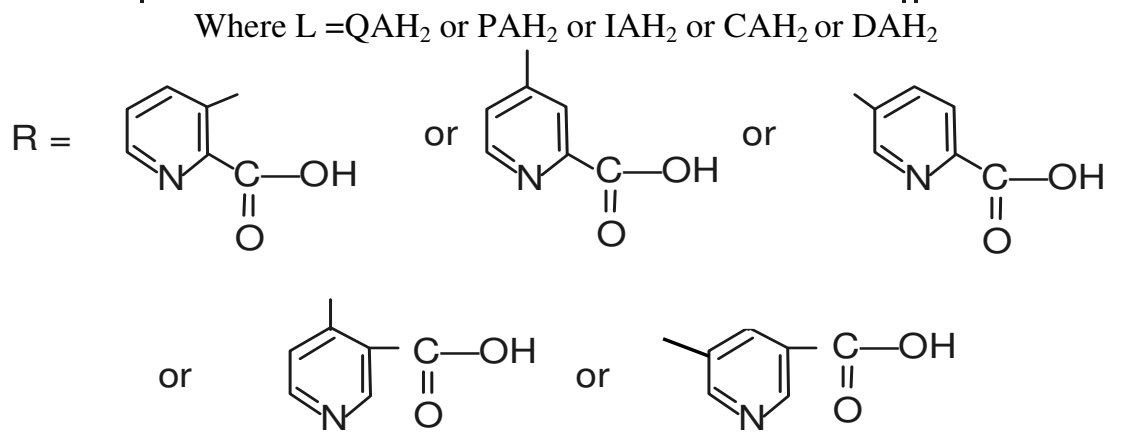

Figure 2. Proposed structure of the complexes 


\section{References}

1. Dutta R L and Ghosh S, Inorg Nuc Chem., 1966, 28, 247.

2. Dutta R L and Ghosh S, J Indian Chem Soc., 1967, 44, 273.

3. Casellato U and Vigato P A, Coord Chem Rev., 1978, 26, 85.

4. Ghosh S, Banerjee T K and Ray P K, J Indian Chem Soc., 1978, 55, 610.

5. Erikson T E, Grenthe I and Puigdomenech I, Inorg Chim Acta, 1987,126, 131.

6. Ducommun Y, Helm L, Laurenezy G and Merbach A, Inorg Chim Acta, 1989, 158, 3-4.

7. $\quad$ Bailey G F, Karp S and Sacs T E, J Bacteriol., 1965, 89, 984-989.

8. Setlow B and Setlow P, Appl Environ Microbiol., 1993, 59(2), 640-643.

9. Meyer R, Brink S, van Rensburg C E J, Joone G K, Gorls H and Lotz S, J Organomet Chem., 2005,690, 117-125.

10. Mokdsi G and Harding M M, Metal-Based Drugs., 1998, 5, 207-215.

11. Boyles J R, Baird M C, Campling B G and Jain N, J Inorg Biochem., 2001, 84,159-162.

12. Causey P W, Baird M C and Cole S P C, Organometallics, 2004, 23, 4486-4494.

13. Allen O R, Croll C, Gott A I, Knox R J and McGowan P C, Organometallics, 2004, 23, 288-292.

14. Claffey J, Muller-Bunz H and Tacke M, J Organomet Chem., 2010, 695, 2105-2117.

15. Hogan M, Gleeson B and Tacke M, Organometallics, 2010, 29, 1032.

16. Hogan M, Gleeson B and Tacke, M, Lett Drug Des Discov., 2010, 7(5), 310-317.

17. Dixit S C, Sharan R and Kapoor R N, J Organomet Chem., 1987, 332, 135.

18. Vogel A I, A Text Book of Practical Organic Chemistry, Longman Green, London, 1948.

19. Fritz H P, Adv Organomet Chem., 1964, 1, 262.

20. Jain S C and Labdev, J Sci Tech., 1970, 8A(4), 169.

21. Sinha S P, Spectrochim Acta, 1964, 20, 879.

22. Sharan R, Gupta G and Kapoor R N, J Less-Common Met., 1978, 60, 171.

23. Dixit S C, Sharan R and Kapoor R N, Inorg Chim Acta, 1989, 158, 109.

24. Dixit S C, Sharan R and Kapoor R N, Inorg Chim Acta, 1988, 145, 39. 


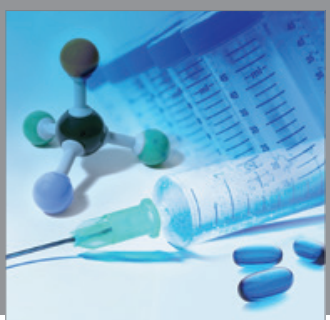

International Journal of

Medicinal Chemistry

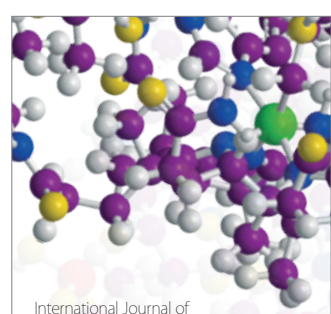

Carbohydrate Chemistry

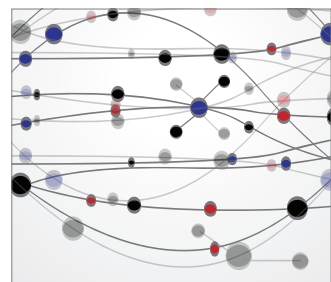

The Scientific World Journal
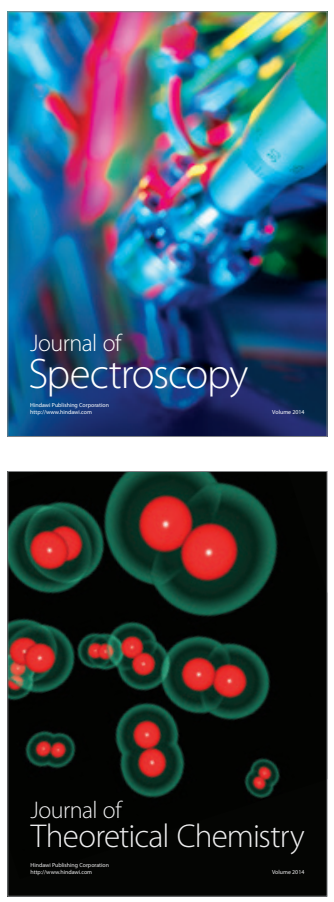
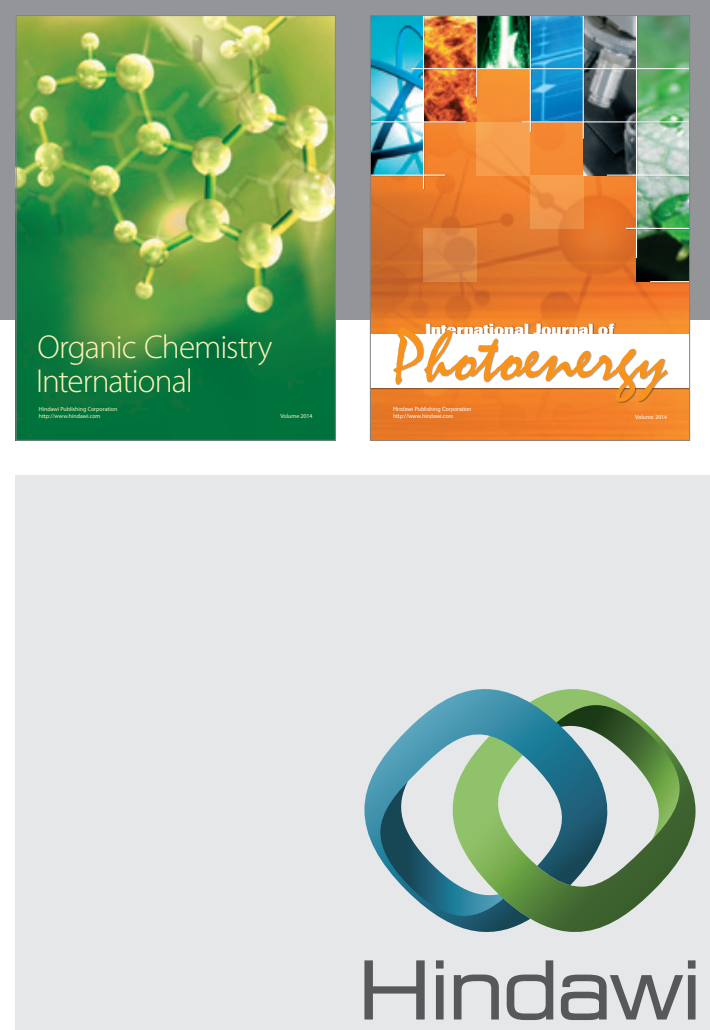

Submit your manuscripts at

http://www.hindawi.com
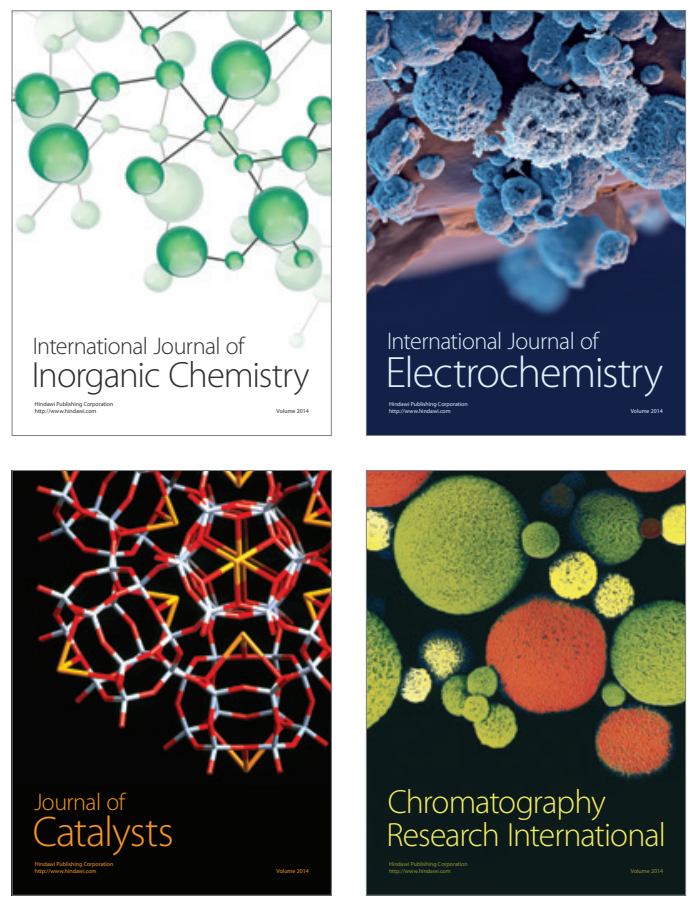
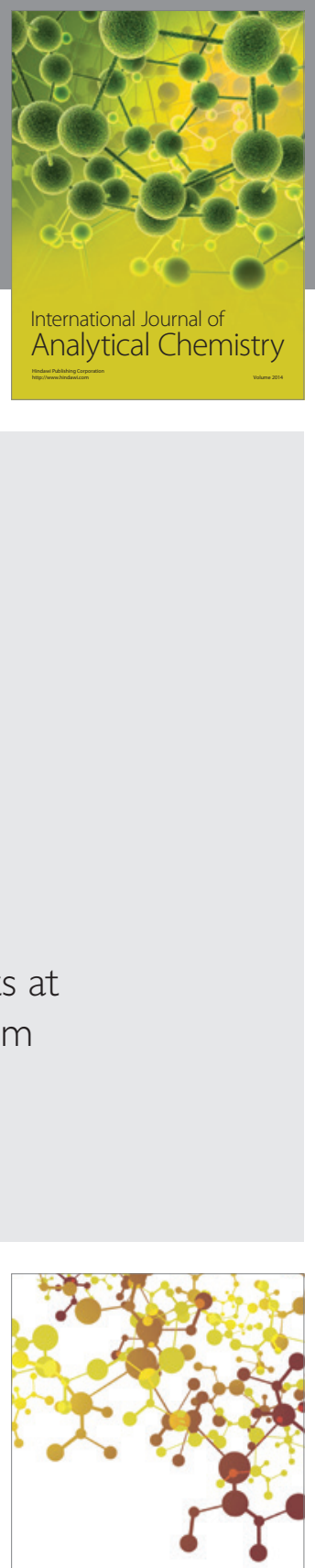

Journal of

Applied Chemistry
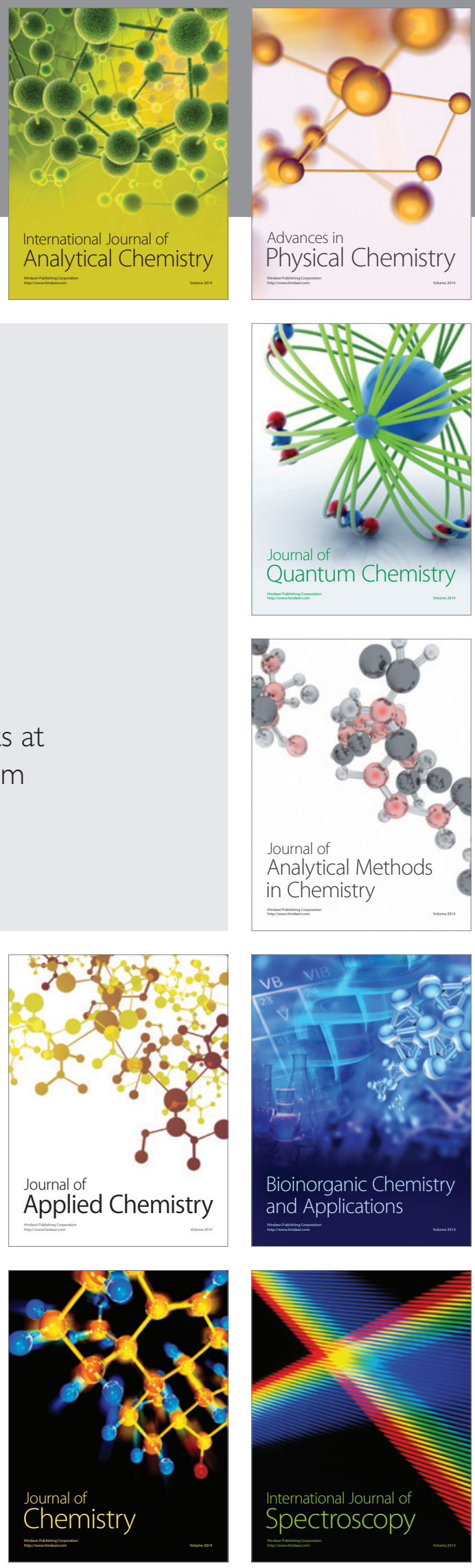